\title{
Incidence of bacterial blight pathogen Pseudomonas syringae pv. pisi in pea seeds grown in Rajasthan, India
}

\author{
Ashwani Kumar Verma ${ }^{1}$, Pooja Arora ${ }^{2}$ and Kailash Agrawal \\ Department of Botany, \\ University of Rajasthan, Jaipur-302 001, India \\ Received: 21-04-2015 \\ Accepted: 04-07-2015
}

DOI:10.18805/lr.v0iOF.8606

\section{ABSTRACT}

Seeds of pea (Pisum sativum L.) originated from various districts of Rajasthan, India were collected and tested from 2010 to 2014 for the presence of seed borne bacterial pathogen namely Pseudomonas syringae pv. pisi causing bacterial blight of pea. The pathogen was identified using morphological, cultural, biochemical, pathogenicity and host tests followed by 16S rRNA based molecular characterization. The results showed that these strains belonged to Pseudomonas syringae pv. pisi. The partial 16S rRNA sequences obtained were deposited in the database of Genebank, NCBI (Acc. No. KF251036). The incidence of the pathogen was recorded 3.5 to $91.5 \%$ in pea seed samples collected from 25 districts of Rajasthan. The results showed that highest (91.5\%) incidence was recorded in Tonk, followed by Jaipur (87\%) and Dausa (85.5\%) while lowest incidence recorded in pea seed samples from Ajmer (3.5\%).

Key words: Incidence, Molecular characterization, Pea seeds, Pseudomonas syringae pv. pisi.

\section{INTRODUCTION}

Legumes are the most important protein supplement in the vegetarian diet. India stands first in the production and area under legumes in the world. Peas have significant amount of vitamins and minerals and with a relatively high antioxidant activity and cholesterol lowering effect (Han and Baik, 2008). Pea is also a good source of dietary fibre (Santos et al., 2014). In India, pea crop is mainly grown in Uttar Pradesh, Haryana, Rajasthan, Punjab, Jammu \& Kashmir and Madhya Pradesh. The crop is cultivated in 0.78 million ha with an annual production of 0.71 million tonnes. In Rajasthan, it is cultivated in 5231 ha with an annual production of 9,000 tonnes (Anonymous, 2014).

Seeds are generally associated with certain pathogens like bacteria, fungi and nematodes etc. which perpetuate in the seed lots on favourable conditions. Pathogens present in almost any seed lot of economically important crop which may be disastrous if introduced into disease free areas therefore seed must be substantially free from inoculums with high level of germination and purity before sowing (Rathod et al., 2012). Pea (Pisum sativum L.) seeds are of great nutritional value due to high quality protein and energy content and are important in global agriculture, providing biologically fixed nitrogen, breaking cereal disease cycles and contributing to locally grown food and feed (Kotlarz et al., 2011).

Seed borne phytopathogenic bacteria are of great concern, as they are responsible for the introduction of new diseases into new areas as well as re-emergence of diseases of the past (Gitaitis and Walcott, 2007). Pseudomonas syringae pv. pisi, the causal agent of pea bacterial blight is the most damaging pathogen (Bradbury, 1986, Martin-Sanz et al., 2013). To identify the bacterial pathogens 16s rRNA gene sequence analysis are generally used (Garcia-Martinez et al., 2001, Sacchi et al., 2002). Bacterial blight is the world's most important disease of pea which is considered to be one of the limiting factors in pea cropping (Lawyer and Chun, 2001, Hollaway et al., 2007). The symptoms of the disease can be characterized by elliptical water-soaked lesions turning into brown necrotic areas. The present study was conducted to isolate and identify the bacterial pathogen in pea seed samples and to determine the prevalence and incidence of pea bacterial blight in Rajasthan, India.

\section{MATERIALS AND METHODS}

Survey and seed samples collection: Field surveys were carried out in different districts of Rajasthan during 20102014 to know the status of bacterial blight of pea. During field surveys a total of 127 seed samples were collected and brought to the laboratory for isolation of the pathogen.

Isolation, purification and preservation: Pea seeds were washed with sterile distilled water and then rinsed with $2 \%$ (v/v) $\mathrm{NaOCl}$ for $2 \mathrm{~min}$. followed by 2-3 rinses in sterile double distilled water. Four hundred seeds per samples (200 seeds untreated and 200 seeds pretreated with aqueous solution of $2 \%$ sodium hypochlorite for $2 \mathrm{~min}$.) were examined on standard blotter method and semi-selective agar medium King's medium B (Anonymous, 1985; Khare and Bhale, 2014) for the presence of bacteria with seed. The

*Corresponding author's e-mail: ashwani14286@gmail.com; 'Present address: Dept. of Botany, Govt. R. R. College, Alwar (Rajasthan).

${ }^{2}$ Biological Sciences, Indian Institute of Sciences, Bangalore. 
bacterial colonies developed on $\mathrm{KmB}$ agar were serially diluted followed by spread-plating $(0.1 \mathrm{ml})$ and plates were incubated at $37^{\circ} \mathrm{C}$ for 24 hours. The pure colonies were isolated, sub-cultured and preserved in $10 \%$ glycerol and kept at $-20^{\circ} \mathrm{C}$ refrigerator for subsequent molecular identification.

Morphological, cultural and biochemical characterization: Gram staining and $\mathrm{KOH}$ solubility test (Lelliot and Stead, 1987) were performed as morphological test. Purified isolates were further characterized by biochemical analysis using LOPAT (Levan formation, oxidase test, potato soft rot test, arginine dihydrolase test, tobacco hypersensitivity reaction test), catalase activity, gelatine liquefaction, Nitrate reduction, $\mathrm{H}_{2} \mathrm{~S}$ production, aesculin hydrolysis, utilization of carbohydrate and pathogenicity test (Kovacs, 1956, Thornley, 1960, Hildebrand and Schroth, 1972, Lelliot and Stead, 1987, Mortensen, 1994a, b, Fahy and Pershey, 1983).

\section{Molecular characterization of the isolate}

Genomic DNA isolation: For Genomic DNA extraction, the bacteria were grown in Nutrient Broth in an incubator shaker at $28^{\circ} \mathrm{C}$ for 24 hours. Two $\mathrm{ml}$ of $24 \mathrm{hr}$ old cultures were centrifuged at 10,000 rpm for $5 \mathrm{~min}$. Supernatant was drained and the pellet was resuspended in $450 \mu \mathrm{L}$ Tris-EDTA (TE) buffer. $45 \mu \mathrm{L} 10 \%$ SDS and $10 \mu \mathrm{L}$ RNase A $(15 \mathrm{mg} / \mathrm{mL})$ were added to the pellet, mixed well by pipetting and incubated for $1 \mathrm{hr}$ at $37^{\circ} \mathrm{C}$ in a water bath. To the lysed samples $1 \mathrm{ml}$ of 1:1 phenol: chloroform was added and mixed well. The samples were centrifuged at $10,000 \mathrm{rpm}$ for $15 \mathrm{~min}$ at room temperature. The aqueous layers were separated in fresh $1.5 \mathrm{ml}$ vial $50 \mu \mathrm{L}$ Sodium acetate and $300 \mu \mathrm{L}$ Isopropanol were added and mixed well. The mixture was centrifuged at $10,000 \mathrm{rpm}$ for $10 \mathrm{~min}$ at room temperature. The supernatant was washed with $1 \mathrm{~mL} \mathrm{70 \%} \mathrm{chilled} \mathrm{ethanol,} \mathrm{mixed} \mathrm{gently} \mathrm{by}$ inverting the tube and centrifuged at $10,000 \mathrm{rpm}$ for $5 \mathrm{~min}$ at $4^{\circ} \mathrm{C}$. The tubes were drained and allowed to dry. The DNA was suspended in $50 \mu \mathrm{L} \mathrm{TE}$ buffer and stored at $4^{\circ} \mathrm{C}$.

PCR Amplification and sequencing: The $16 \mathrm{~S}$ ribosomal RNA was amplified by using the thermocycler (Applied Biosystems Veriti Thermal cycler) with Hi-Media Taq DNA polymerase, QIAGEN dNTPs and primers 8f (52 AGA GTTTGATCATGGCTCAG) and 1492 R(52 CGGTTACCTTGTTACGACTT). The reactions were set out as follows: initial denaturation at $94^{\circ} \mathrm{C}$ for $3 \mathrm{~min}, 35$ cycles at $94^{\circ} \mathrm{C}$ for $1 \mathrm{~min}, 58^{\circ} \mathrm{C}$ for $1 \mathrm{~min}$ for annealing, $72^{\circ} \mathrm{C}$ for $1 \mathrm{~min}$ for extension and final extension at $72^{\circ} \mathrm{C}$ for $10 \mathrm{~min}$ and final hold at $4^{\circ} \mathrm{C}$. The amplified product was detected by agarose gel electrophoresis and visualized by gel documentation system (BIO-RAD 170-8170EDU) with ethidium bromide staining. The PCR product obtained was sequenced by an automated DNA sequencer (ABI PRISM 377-96 Genetic Analyzer, Applied Biosystems). Partial 16S rRNA gene sequence was analyzed with nucleotide BLAST search in GenBank. 16S rRNA sequence was then submitted to the GenBank, NCBI, USA.
Incidence of Bacterial Pathogen: To study the incidence of identified bacterial pathogen, all the 127 seed samples collected were directly plated on King's medium B for Pseudomonas syringae pv. pisi (Mohan and Schaad,1987; Mortensen, 1994a).

\section{RESULTS AND DISCUSSION}

Many diseases have been found associated with pea crop caused by fungi, bacteria and viruses. The aim of this research was to identify the bacterial blight disease pathogen associated with pea seeds grown in Rajasthan state of India. Bacterial blight of pea, caused by Pseudomonas syringae pv. pisi (Sackett) Young, Dye and Wilkie (Sackett, 1916) is mainly responsible for reduction in yield and seed quality following epidemics (Taylor , 1972; Bradbury, 1986;; Cirvilleri et al., 2007). The pathogen was first identified in Colorado, USA (Sackett, 1916) and was subsequently found in all pea producing countries (Lawyer and Chun, 2001).

Morphological and biochemical characterization: The isolate of $P$. syringae pv. pisi was confirmed by pathogenicity tests and different biochemical tests. The identification of bacterial pathogen was first carried out on the basis of biochemical characteristics and pathogenicity test. On King's medium B, white-yellowish, green diffusible pigment producing and convex smooth colonies appeared. The bacterial colonies showed typical blue-green fluorescence under UV light (360 nm) were subjected to various cultural and biochemical diagnostic tests for identification (Table 1). Identifications based on exclusively biochemical characterization are uncertain as the pathovars of $P$. syringae are very similar in their biochemical profiles and symptomatology. Moreover, other Pseudomonas species,

Table 1: Summary of the identification based on biochemical and host test of bacterial isolates (Pseudomonas syringae pv. pisi) isolated from pea seeds

\begin{tabular}{|c|c|c|}
\hline \multicolumn{2}{|c|}{ Characteristics } & $\begin{array}{c}\text { Pseudomonas } \\
\text { syringae pv.pisi }\end{array}$ \\
\hline \multirow{2}{*}{\multicolumn{2}{|c|}{$\begin{array}{l}\text { Gram stain reaction } \\
\mathrm{KOH} \text { test }\end{array}$}} & - \\
\hline & & + \\
\hline \multirow[t]{5}{*}{ LOPAT } & $\begin{array}{l}\text { Levan formation on sucrose } \\
\text { nutrient agar (SNA) }\end{array}$ & + \\
\hline & Oxidase test & - \\
\hline & Potato soft rot test & - \\
\hline & Arginine dihydrolase test & - \\
\hline & $\begin{array}{l}\text { Tobacco hypersensitivity } \\
\text { response }\end{array}$ & + \\
\hline \multicolumn{2}{|c|}{ Fluroscence on King's medium B } & + \\
\hline \multicolumn{2}{|c|}{ Gelatin liquefaction } & + \\
\hline \multicolumn{2}{|c|}{$\mathrm{H}_{2} \mathrm{~S}$ production } & $+/ \mathrm{w}$ \\
\hline \multicolumn{2}{|c|}{ Aesculin hydrolysis test } & + \\
\hline \multicolumn{2}{|c|}{ Nitrate reduction test } & $+/ \mathrm{w}$ \\
\hline \multicolumn{2}{|c|}{ Utilization of carbohydrates } & + \\
\hline \multicolumn{2}{|c|}{ Pathogenicity test } & $\begin{array}{l}\text { Water soaked } \\
\text { chlorotic lesions }\end{array}$ \\
\hline \multicolumn{2}{|c|}{ Host test on pea plant } & + \\
\hline \multicolumn{2}{|c|}{ Host test on other plants } & $-/ \mathrm{w}$ \\
\hline
\end{tabular}


such as $P$. viridiflava, $P$. fluorescence and some soft-rotting Pseudomonas, have been isolated from pea plants with bacterial blight symptoms (Taylor, 1972; Martin-Sanz et al., 2011). Molecular tools for the identification of bacteria were used in this study and $16 \mathrm{~S}$ rRNA gene analysis was intensively used to understand the phylogenetic relationships. Molecular characterization: The isolated genomic DNA was electrophoresed on 1\% agarose gel stained with ethidium bromide. The genomic DNA was observed under UV transilluminator. The PCR reaction mix was analyzed by agarose gel electrophoresis and the DNA of the expected size was purified and sequenced (Fig 1). Partial sequence of 807 bp was obtained and isolates was identified as Pseudomonas syringae pv. pisi based upon the similarity search of $16 \mathrm{~S}$ rRNA sequence in the NCBI GenBank database. It has been assigned Pseudomonas syringae pv. pisi strain Psp-2529 and was submitted to the Genbank (KF251036).
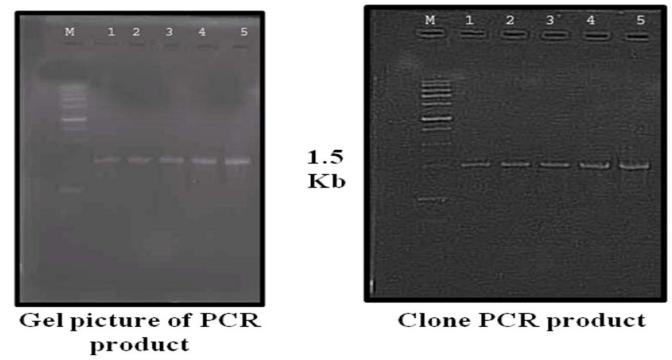

Fig 1: Gel picture of amplified 16srDNA
Incidence of bacterial pathogen: Seed assays are the most reliable methods for determining infection of seed-borne pathogens (Karavina et al., 2007). The pathogen was confirmed in 125 samples, out of one hundred and twenty seven seed samples studied on King's medium B with an incidence range of 3.5-91.5\% from 25 districts of Rajasthan. Seed samples collected from Alwar, Baran, Bharatpur, Bikaner, Bundi, Churu, Chittorgarh, Dausa, Dungarpur, Jaipur and Nagaur districts of Rajasthan carried higher incidence of the pathogen. The highest bacterial blight incidence was recorded in Tonk $(91.5 \%)$, followed by Jaipur $(87 \%)$ and Dausa $(85.5 \%)$ while lowest incidence was recorded in pea seed samples from Ajmer (3.5\%) (Table 2). The collected seeds showed increasing higher incidence of the pathogen which cause seed deterioration, reduces quality and yield of the crop. Chakravarthy et al. (2004) reported 1 to $90 \%$ varying incidence of Xanthomonas axonopodis pv. cyamopsidis causal agent of bacterial blight on cluster bean in Karnataka while in Rajasthan, 7.5 to $100 \%$ incidence of the same pathogen have been reported (Agrawal et al., 2011, Jain and Agrawal, 2011). Detection of the bacterial pathogen in seed samples has a decisive role in control of related plant diseases and preventing economic losses. Resistant cultivars, crop rotation and use of pathogen-free seeds may help in controlling bacterial blight of pea in Rajasthan, India.

Table 2: District wise occurrence and percent incidence range of bacterial pathogen (Pseudomonas syringae pv. pisi) in seed samples of pea in incubation methods (200 seeds/sample)

\begin{tabular}{|c|c|c|c|c|}
\hline \multirow{2}{*}{$\begin{array}{l}\text { Districts of } \\
\text { Rajasthan }\end{array}$} & \multirow{2}{*}{$\begin{array}{c}\text { No. of seed } \\
\text { samples studied }\end{array}$} & \multicolumn{2}{|c|}{ Bacterial Oozing in Standard blotter method (SBM) } & \multirow{2}{*}{$\begin{array}{c}\begin{array}{c}\text { Semi-selective } \\
\text { agar media }\end{array} \\
\text { PSP on KmB agar }\end{array}$} \\
\hline & & Untreated seeds & Pre-treated seeds & \\
\hline Ajmer & 4 & $4(3.5-6.5)$ & $4(2.5-4)$ & $4(3.5-5.5)$ \\
\hline Alwar & 6 & $6(10.5-23.5)$ & $6(8.5-18)$ & $6(32.5-58)$ \\
\hline Baran & 4 & $4(6.5-33.5)$ & $4(4-31)$ & $4(23-46.5)$ \\
\hline Bharatpur & 3 & $3(3-16.5)$ & $3(2-11.5)$ & $3(19.5-62)$ \\
\hline Bhilwara & 2 & $2(2.5-5)$ & $2(2.5-4)$ & $2(5-13.5)$ \\
\hline Bikaner & 7 & $7(9.5-20)$ & $7(8-19.5)$ & $7(12-48.5)$ \\
\hline Bundi & 4 & $4(3.5-18.5)$ & $4(2.5-15)$ & $4(10.5-28)$ \\
\hline Churu & 2 & $2(8.5-29)$ & $2(5.5-22.5)$ & $2(15-56.5)$ \\
\hline Chittorgarh & 9 & $9(9.5-28)$ & $9(6-25)$ & $9(20-50.5)$ \\
\hline Dausa & 6 & $6(12-62.5)$ & $6(10.5-61)$ & $6(20-85.5)$ \\
\hline Dholpur & 5 & $5(3.5-12)$ & $5(3-10.5)$ & $5(9.5-32)$ \\
\hline Dungarpur & 4 & $4(2.5-14.5)$ & $4(1.5-12.5)$ & $4(11.5-35)$ \\
\hline Jaipur & 7 & $7(8.5-90)$ & $7(7-85)$ & $7(8.5-87)$ \\
\hline Jhalawar & 2 & $2(6.5-42.5)$ & $2(6-42.5)$ & $2(7.5-41.5)$ \\
\hline Jhunjhunu & 2 & $2(9.5-52.5)$ & $2(8.5-47)$ & $2(8.5-80.5)$ \\
\hline Jodhpur & 7 & $7(10.5-75)$ & $7(9-70.5)$ & $7(9-82.5)$ \\
\hline Kota & 6 & $6(3.5-22.5)$ & $6(3-20.5)$ & $6(6.5-60)$ \\
\hline Nagaur & 5 & $5(7.5-40.5)$ & $5(6.5-36)$ & $5(10-56)$ \\
\hline Pali & 6 & $6(3-21.5)$ & $6(2.5-18)$ & $5(4.5-48)$ \\
\hline Pratapgarh & 6 & $6(4.5-32)$ & $6(3-28.5)$ & $6(6.5-39)$ \\
\hline Rajsamand & 5 & $5(10.25-46.50)$ & $5(8.25-45.50)$ & $4(8-58.25)$ \\
\hline Sawaimadhopur & 3 & $3(5-63.5)$ & $3(5-57.5)$ & $3(7-82.5)$ \\
\hline Sirohi & 5 & $5(3-25.5)$ & $5(3.5-25)$ & $5(9.5-47)$ \\
\hline Tonk & 8 & $8(6.5-70)$ & $8(5-68.5)$ & $8(5-91.5)$ \\
\hline Udaipur & 9 & $9(5-45.5)$ & $9(3-37.5)$ & $9(9-29.5)$ \\
\hline Total & 127 & $127(2.5-90)$ & $127(1.5-85)$ & $125(3.5-91.5)$ \\
\hline
\end{tabular}

(PSP-Pseudomonas syringae pv. pisi, KmB-Kings medium B agar; The figures in parentheses are the percent incidence range) 


\section{REFERENCES}

Agrawal K. and Jain, R. (2011). Seed borne bacterial diseases of cluster bean and their management. J. Indian Bot. Soc. suppl. vol.:301-308.

Anonymous, (1985). International rules for seed testing association (ISTA). Seed Sci. Technol., 4: 3-49.

Anonymous, (2014). Agricultural Statistics. http:// www.krishi.rajasthan.gov.in /Departments/Agriculture/mainhindi.asp?t= statics_top.htm\&p=statics_index_new.htm.

Bradbury, J.F. (1986). Guide to Plant Pathogenic Bacteria. CAB International Mycological Institute, New York, USA, pp: 332.

Chakravarthy, C.N., Krishnappa, M. and Thippeswamy, B. (2004). Investigation on bacterila blight (Xanthomonas axonopodis pv. cymopsidis) of cluster bean [Cymopsis tetragonoloba (L.) Taub.] and in vitro control. Indian J. Plant Pathol., 22: 68-74.

Cirvilleri, G., Scuderi, G., Catara, V. and Scortichini, M. (2007). Typing of Pseudomonas syringae pv. pisi strains by fluorescent AFLP fingerprinting. J. Plant Pathol., 89: 421-425.

Fahy, P.C. and Persley, G.J. (1983). Plant Bacterial Diseases: A Diagnostic Guide. Academic Press, Sydney, London, pp: 393.

Garcia-Martinez, J., Bescos, I., Rodriguez-Sala, J.J. and Rodriguez-Valera, F. (2001). RISSC: A novel database for ribosomal 16S-23S RNA genes spacer regions. Nucleic Acids Res., 29: 178-180.

Gitaitis, R. and Walcott, R. (2007). The epidemiology and management of seedborne bacterial diseases. Ann. Rev. Phytopathol., 45: 371-397.

Han, H. and Baik, B.K. (2008). Antioxidant activity and phenolic content of lentils (Lens culinaris), chickpeas (Cicer arietinum L.), peas (Pisum sativum L.) and soybeans (Glycine max) and their quantitative changes during processing. Int. J. Food Sci. Technol., 43: 1971-1978.

Hildebrand, D.C. and Schroth, M.N. (1972). Identification of fluorescent pseudomonas. Proceedings of the 3rd International Conference on Plant Pathogenic Bacteria, April 14-21, 1971, Wageningen, The Netherlands, pp. 281-287.

Hollaway, G.J., Bretag, T.W. and Price, T.V. (2007). The epidemiology and management of bacterial blight (Pseudomonas syringae pv. pisi) of field pea (Pisum sativum) in Australia: A review. Aust. J. Agric. Res., 58: 1086-1099.

Jain, R. and Agrawal, K. (2011). Bio-efficacy of plant extracts against Pseudomonas syringae pv. syringae causing leaf spot of Cluster bean. Ann. Plant Prot. Sci., 19: 106-112.

Karavina, C., Chihiya J. and Tigere, T.A. (2007). Detection and characterization of Xanthomonas phaseoli (E. F. SM) in common bean (Phaseolus vulgaris) seeds collected in Zimbabwe. J. Sustainable Dev. Afr., 10: 105-119.

Khare, D. and Bhale, M.S. (2014). Seed Technology. Scientific Publishers, India, pp. 944.

Kotlarz, A., Sujak, A., Strobel W. and Grzesiak, W. (2011). Chemical composition and nutritive value of protein of the pea seeds-effect of harvesting year and variety. Veg. Crops Res. Bull., 75: 57-69.

Kovacs, N., (1956). Identification of Pseudomonas pyocyanea by the oxidase reaction. Nature, 178: $703-703$.

Lawyer, A.S. and Chun, W. (2001). Foliar Disease Caused by Bacteria. In: Compendium of Pea Diseases and Pests, [Kraft, J.M. and F.L. Pfleger (Eds.)]. $2^{\text {nd }}$ Edn., APS Press, St. Paul, pp. 22-24.

Lelliot, R.A. and Stead, D.E. (1987). Methods for the Diagnosis of Bacterial Diseases of Plants. In: Methods in Plant Pathology, Preece, T.F. (Ed.). Blackwell Science, Oxford, pp. 2-216.

Martin-Sanz, A., Palomo, J.L., Vega, M.P.D.L. and Caminero, C. (2011). Identification of pathovars and races of Pseudomonas syringae, the main causal agent of bacterial disease in pea in North-Central Spain, and the search for disease resistance. Eur. J. Plant Pathol., 129: 57-69.

Martin-Sanz, A., Vega, M.P. de la, Murillo, J. and Caminero, C. (2013). Strains of Pseudomonas syringae pv. syringae from pea are phylogenetically and pathogenically diverse. Phytopath., 103: 673-681.

Mohan, S.K. and Schaad, N.W. (1987). An improved agar plating assay for detecting Pseudomonas syringae pv. syringae and P. s. pv. phaseolicola in contaminated bean seed. Phytopath., 77: 1390-1395.

Mortensen, C.N. (1994a). Seed Health Testing for Bacterial Pathogens. Danish Government Institute of Seed Pathology for Developing Countries, Copenhagen, Denmark, pp. 68.

Mortensen, C.N. (1994b). Seed Bacteriology Laboratory Guide. Danish Government Institute of Seed Pathology for Developing Countries, Copenhagen, Denmark, pp. 102.

Rathod, L.R. and Pawar, P.V. (2012). Antimicrobial activity of medicinal plant to control seed borne pathogen of soybean. Curr. Bot., 3: 10-12.

Sacchi, C.T., Whitney, A.M., Mayer, L.W., Morey, R. and Steigerwalt, A. (2002). Sequencing of 16S rRNA gene: A rapid tool for identification of Bacillus anthracis. Emerg. Infect. Dis., 8: 1117-1123.

Sacket, W.G. (1916). A bacterial stem blight of field garden peas. Bull. of the Colorado Agri. Experimental Station. 217: 3-43.

Santos, J., Oliveira, M.B.P.P., Ibanez E. and Herrero, M. (2014). Phenolic profile evolution of different ready-to-eat babyleaf vegetables during storage. J. Chromatogr. A., 1327: 118-131.

Taylor, J.D. (1972) Races of Pseudomonas pisi and sources of resistance in field and garden peas. N. Z. J. Agric. Res., 15: 441-447.

Thornley, M.J. (1960). The differentiation of pseudomonas from other gram negative bacteria on the basis of arginine metabolism. J. Applied Bacteriol., 23:37-52. 